\title{
Do Audit Committees Reduce the Agency Costs of Ownership Structure?
}

\author{
CHARLIE X. CAI, DAVID HILLIER, GAOLIANG TIAN, QINGHUA WU
}

\begin{abstract}
We investigate the agency costs of corporate ownership structure and the role of audit committees in mitigating their effect. Using China as a laboratory, where audit committees are voluntary, we study the demand for and value relevance of audit committees conditional on the various agency costs of corporate ownership. Audit committees complement existing internal governance systems by reducing the agency conflicts embedded in ownership structure. They are always value relevant, the magnitude of which depends upon the level and complexity of the ownership lattice. Audit committees substitute for inefficient external regulatory environments, particularly where weak legal institutions predominate. Our results are robust to firm size, investment level and financial leverage.
\end{abstract}

Keywords: State-owned Enterprises; Corporate Governance; Auditing; Audit Committee; Ownership Pyramids.

The authors are from the University of Bradford (Cai), University of Strathclyde (Hillier), Xi'an JiaoTong University (Tian) and Fudan University (Wu). Corresponding Author: David Hillier, University of Strathclyde, UK; E-mail address david.hillier@strath.ac.uk. Gaoliang Tian recognises the financial support from NSFC (70772110). We would like to thank participants at the American Accounting Association 2009 annual meeting, Chulalongkorn University, Universitat Autonoma de Barcelona, University of Leeds, and the University of Salamanca for their helpful comments. All errors are our responsibility. 


\section{INTRODUCTION}

Since Jensen and Meckling’s (1976) discussion of the implicit and explicit contracts between owners and managers, research has improved our understanding of the agency costs relating to the separation of ownership and control. However, it is documented in a global context that the diffused shareholdings underlying Jensen and Meckling (1976) are not the norm in most countries. Instead, concentrated, pyramid, and state ${ }^{1}$ ownership structures are far more common (La Porta et al., 1999; Claessens et al., 2002; Fan et al, 2011; Huyghebaert and Wong, 2012; Duchin and Sosyura, 2012; Boubakri et al., 2013).

In this paper, we investigate whether audit committees offset any negative valuation effects from having specific shareholder structures, such as state shareholders or pyramid holdings. Financial reporting quality is at the very foundation of good governance and a central mechanism for reducing a firm's agency costs. Literature has also shown that audit committees enhance managerial accountability and are an effective component of corporate governance. Since audit committees provide better quality assurance, their usefulness should increase in response to the level of inherent agency problems within a firm. ${ }^{2}$

Whereas in most developed markets, audit committees are necessary for stock exchange listing, in China they are optional. By examining the determinants of audit committee formation and analyzing the moderating impact of ownership structure, we are able to disentangle the agency cost of controlling ownership (state versus private, pyramid versus direct shareholdings) and its effect on corporate value. In this regard, we employ a comprehensive sample of Chinese firms immediately following government-instigated

\footnotetext{
In this paper, the terms, 'state' and 'government' are used interchangeably.

2 There is a large body of research, theoretical and empirical, that considers how audit committees contribute to the internal corporate governance process and improve financial reporting quality. Recent examples include Defond et al. (2005), Karamou and Vafeas (2005), Krishnan (2005), Vafeas (2005), Gaynor, et al. (2006), Abbott, et al. (2007), Chen and Zhou (2007), Lennox and Park (2007), Archambeault, et al. (2007), Krishnan and Visvanathan (2008), Beasley et al. (2009), Goh (2009), Hoitash, et al. (2009), Magilke, et al. (2009), Naiker and Sharma (2009), Caskey, et al. (2010), Engel et al. (2010), Ghosh et al. (2010), and Price, et al. (2010).
} 
corporate reforms during which audit committees were formally encouraged but not obligatory.

Our core empirical analysis presents evidence that privately-owned companies are more likely to have an audit committee when the cash flow rights of the controlling owner are at either extreme of the ownership distribution. This is in contrast to state-owned firms where the presence of an audit committee is invariant to the level of the state shareholder's cash flow rights. We also document that audit committees are value relevant, particularly in firms with severe agency relationships. Keeping the source of ownership constant, audit committees are more likely to be found in companies that have stronger levels of corporate governance, such as when there are more non-executive directors, more frequent board meetings, and a larger board. We also find that they are associated with firms where the chairman and chief executive role is combined. At the firm level, audit committees appear to complement other forms of good corporate governance. However, we find that audit committees are more common in weak legal environments and appear to substitute for a lack of resilient external governance structures.

\section{REGULATORY ENVIRONMENT AND LITERATURE REVIEW}

In order to improve the quality of listed companies and establish a modern corporate governance culture in China, the Chinese Security Regulation Commission (CSRC) and the National Economic and Trade Commission (NETC) have issued a number of regulations and guidelines on corporate governance. The most important document is the "Code for Corporate Governance of Listed Companies” issued by the CSRC and the NETC in January 2001. 
A major component of the Code is the recommendation that committees for strategy, audit, remuneration, and nomination be formed. Unlike other countries, the formation of board sub-committees, such as the audit committee, is not obligatory but encouraged. It is not uncommon to see company directors on their own audit committee. However, the majority of audit committee members should be independent and at least one individual should have financial expertise.

\section{Ownership Structure in China}

The objectives and performance of corporate managers will, naturally, be influenced by the objectives of shareholders. For example, socio-political agendas will be an important driver of managerial behavior in firms with state-shareholders, whether they relate to a capping of profits, a targeted investment strategy or positive employment practices. In addition, state shareholders are unlikely to have specialized knowledge of a firm's operations, allowing managers some scope in pursuing their personal objectives. Executive turnover and bonuses also tend to be less in firms with state shareholdings (Boycko et al., 1996; Dewenter and Malatesta, 2001). Collectively, these characteristics can impose a significant disincentive to corporations with any form of state ownership to maximize firm performance and improve financial reporting quality.

In most Chinese firms, the state has a major shareholding and private or state-owned commercial firms comprise the other shareholder groups (Lui and Tian, 2012). With different shareholder identities, Chinese firms can have a number of contrasting objectives; shareholder wealth maximization being the more common but not necessarily most important (Chang and Wong, 2009). Thus, to understand the objectives of shareholders and, consequently, management, it is important to identify each firm's ultimate controlling owner. Although firms can have more than one major shareholder, by focusing on the largest 
ultimate owner, we are able to extract the greatest degree of difference across shareholder objectives (La Porta et al., 1999; Claessens et al., 2002; Faccio and Lang, 2002; Lemmon and Lins, 2003; and Fan and Wong, 2002, 2005).

\section{Audit Committees in China}

Faced with a number of different agency relationships, a firm can signal its openness to external scrutiny and transparency by strengthening its corporate governance structure. Options include separating the role of chairman and chief executive, introducing more independent directors with financial expertise onto the board, and openly improving financial reporting quality. In this context, regulatory authorities throughout the world have placed the audit committee, (with its oversight responsibilities for corporate reporting, risk management and internal control), at the heart of any effective corporate governance system. ${ }^{3}$

Audit committees have been shown to improve the quality of corporate decisionmaking in a number of different ways. First and foremost, financial reporting quality is better in firms with an audit committee (Vafeas 2005; Krishnan and Viswanathan 2008; Naiker and Sharma 2009) and this has implications for other areas, such as pay-performance sensitivity (Bushman and Smith, 2001), earnings management (Klein 2002; Xie et al. 2003), the auditorfirm relationship (Abbott et al. 2003; Carcello and Neal 2003; Gaynor et al. 2006; Abbot et al. 2007; Chen and Zhou 2007; Lennox and Park 2007), firm value (Defond et al. 2005), voluntary disclosure practices (Karamou and Vafeas 2005; Archambeault et al. 2008), and internal control (Krishnan 2005; Beasley et al. 2009; Goh 2009; Hoitash et al. 2009).

Given the different objectives between private investors and the State, the demand for an audit committee may be a function of ownership structure. Firms with dominant state

\footnotetext{
3 See, for example, Title III of The Sarbanes-Oxley Act (2002) in the US, Bill 198 (2002) in Canada, The Financial Instruments and Exchange Law (2006) in Japan, and the UK Corporate Governance Code (2010).
} 
shareholders can benefit from political ties that enhance their opportunities (Calomaris et al. 2009; Chen et al. 2010) and may prefer a more opaque financial reporting environment to avoid the scrutiny and possible social sanctions of public attention (Fan and Wong 2005; Wang et al. 2008, Chang and Wong 2009). In privately-controlled firms, it is expected that the overriding objective is to maximize firm value and the quality of financial decisions. As a result, the demand for an audit committee in these firms should a priori be high. However, in a low investor protection environment, there will be substantial private benefits of control and a lack of financial transparency may be preferred by the controlling shareholder (Ali et al. 2007).

\section{HYPOTHESES}

Ali et al. (2007) propose two main agency relationships within exchange-listed corporations. A Type I agency relationship concerns shareholders and management whereas a Type II agency relationship involves majority and minority shareholders. In each case, conflicts between the two parties lead to costs that reduce the value of the firm. Overall, Type I (Manager vs. Shareholder) and Type II (Majority vs. Minority Shareholder) agency relationships are greatest at low and high levels of controlling ownership, respectively, and the need for audit committees is expected to be strongest at these extremes. Given the different agency relationships that can prevail within a firm, an audit committees may be an important signaling mechanism to external stakeholders that management is serious about financial rigor and accountability. ${ }^{4}$

Hypothesis 1. There is a positive relationship between the use of audit committees and the extent to which a firm has extreme Type I and Type II agency relationships.

\footnotetext{
4 Dahya et al (2008) show that firms can reduce the discount from concentrated ownership structures by having more independent directors on the board. Our justification for considering audit committees in firms with state shareholders is an analogous one.
} 
If audit committees mitigate Type I and Type II agency costs or signal that the controlling owner is prioritizing shareholder-wealth maximization, investors will apportion greater value to firms with an audit committee. Given that agency costs are more severe at ownership extremes, we would also expect to see greater valuation effects of audit committees for firms that are widely or closely held.

Hypothesis 2a. There is a positive relationship between the presence of an audit committee and firm value.

Hypothesis $2 b$. There is a positive relationship between the audit committee value premium and the severity of agency costs in a firm.

\section{Subsidiary Hypotheses}

A major assumption in the previous hypotheses is that cash flow rights equate wholly to voting rights and the concepts of ownership and control are synonymous. However, in China, as in many other countries, a variety of multiple class share structures can lead to a separation between cash flow and voting rights. This may result in undesirable agency costs in the form of tunneling and managerial entrenchment (Grossman and Hart, 1988; Harris and Raviv, 1988; La Porta et al., 1999; Fan and Wong, 2005; Bae et al., 2012). For example, relatedparty transactions, as a form of expropriation, rise with voting rights held by the government in state-controlled firms (Huyghebaert and Wang, 2012).

When firms have an ownership-control wedge (i.e., the controlling owner's voting rights are greater than their cash flow rights), the increased transparency and accountability from an audit committee can signal to external stakeholders that the major shareholder is less likely to expropriate wealth from the company. Therefore it is more likely that audit 
committees will be used by firms to mitigate this agency relationship if an ownership-control wedge exists.

Hypothesis 3. There is a positive relationship between the use of an audit committee and the existence of an ownership-control wedge.

Do audit committees reduce the agency costs associated with pyramid ownership structures? An important feature of the Chinese system, which is also prevalent in other countries, is control through pyramidal structures (La Porta et al. 1999; Claessens et al. 2002). Ownership pyramids have been shown to increase the likelihood of tunneling, create inefficient internal markets, and reduce the strategic cohesiveness of firms that comprise the pyramid chain (Bae, Kang and Kim 2002). However, when the controlling owner is the state, a pyramid can be an effective tool to transfer decision rights to management and distance the firm from social and political objectives (Scharfstein and Stein 2000; Fan et al. 2005). This suggests that the need for an audit committee is greater in privately owned firms having a complex pyramid structure than it is for comparable state firms.

Hypothesis 4. Privately owned firms with a complex pyramid ownership structure are more likely to use an audit committee than comparable state-owned firms.

The legal and political environment in which a firm operates will influence the behavior of controlling shareholders and management (Shleifer and Vishney, 1994; Shleifer, 1998; Ball et al., 2000; Fan and Wong, 2002; Johnson and Mitton, 2003; Bushman et al., 2004; Faccio, 2006; Leuz and Oberholzer-Gee, 2008; and Wang et al., 2008). Firms with poor corporate governance and regions with weak external regulatory regimes may require an audit committee to alleviate investor concerns of a heightened likelihood of expropriation from the company. Alternatively, the shareholders of well-governed firms may simply expect an audit 
committee to exist because it is an exemplar of good corporate governance. The question of whether audit committees substitute or complement weaknesses in the external regulatory environment is an empirical one and we choose a particular form to express our hypothesis.

China is an ideal laboratory to investigate the impact of external governance structures because of the significant variation in regulatory environments across the country. Although China is one country, it consists of a number of different provinces and autonomous regions, where political and economic institutions vary considerably in strength. We follow Wang et al. (2008) in considering three components of regulatory governance: credit market development, government decentralization and the strength of the legal environment. If audit committees reduce the agency costs of ownership and substitute for external governance systems, we would expect a negative relationship between the strength of these structures and the likelihood that an audit committee exists. This is because the need for an audit committee is greater in a poor governance environment. However, an alternative hypothesis would be that audit committees are more likely to exist in an environment where external governance structures are strong because it is an expectation that they should be used.

Hypothesis 5. There is a relationship (substitute or complement) between the use of an audit committee and the external regulatory environment.

\section{RESEARCH METHOD AND RESULTS}

The initial sample consists of all listed Chinese firms for the period between 2002 and 2004. In January 2001, Chinese regulators recommended the voluntary formation of audit committees. In addition, data requirements necessitated a 2002 start date since information on ultimate controlling shareholders was only disclosed from financial years beginning in 2001. 
Information on the ultimate controlling shareholder is manually extracted from each firm's annual reports by measuring both the cash flow and voting rights of each major shareholder.

We ended the sample period in 2004 to avoid confounding the effect of other major reforms with our analysis. In 2005, China agreed on a new five-year plan, which introduced a whole raft of economic measures designed to create intensive growth in the country and internationalize its economy. The government also announced a major shareholding reform to eliminate non-tradable shares by 2006. Although these had little immediate impact, the move towards a more diverse international ownership structure will have undoubtedly resulted in a shift in the agency relationships within Chinese firms.

We identify the ultimate controlling shareholder as follows: (1) If the ultimate controlling shareholder is a natural person, non-state enterprise, Employee Stock Ownership Plan (ESOP), collective enterprise, township government department, or foreign-funded enterprise, it is categorized as a privately held firm. (2) If the ultimate controlling shareholder is a central government agency, local government institution, or state university, it is regarded as a state-controlled firm. Agency chains are measured by the number of layers between the ultimate controlling owner and the listed company. If there are many chains of control, the shortest is taken as the pyramidal chain length.

Our sample passed through a number of filters. First, cross-listed and financial firms were excluded because they are subject to more stringent regulatory governance requirements, including a mandatory audit committee. Second, we omit firms that are traded on the Small and Medium Enterprise (SME) Board. The SME Board was introduced by the Shenzhen Stock Exchange in 2004 and requires significantly less regulation and disclosure than the main exchange. Third, we drop any firm where information on the ultimate controlling 
shareholder is not available ${ }^{5}$. After removing companies with insufficient data (lack of accounting, governance data, etc.), the final sample consisted of 1,126 companies spanning 3,217 firm years.

Audit Committee data is manually collected from the "Corporate Governance” or "Board Report” section in corporate annual reports. The annual reports of listed companies are downloaded from the China Securities Regulatory Commission (CSRC) designated information disclosure website - Giant Tidal Information Network. ${ }^{6}$ Board structure and corporate finance variables are drawn from the CSMAR corporate governance and financial reporting database ${ }^{7}$. When missing data is encountered, the financial accounts are manually examined to supplement information in the sample. Variable definitions are summarized in Table 1.

Insert Table 1 about here

Descriptive statistics are reported in Table 2. The characteristics of state-owned and privately controlled firms are economically very similar (although statistically different) with government firms tending to be larger in size and having lower Q ratios. Government firms have more concentrated ownership and control than their privately owned counterparts, with control and cash flow rights of 47.12 percent and 42.59 percent compared to 36.10 percent and 21.11 percent, respectively.

\footnotetext{
${ }^{5}$ Some companies did not disclose the proportion of shares in the pyramidal chain. Missing information in any chain leads to difficulty in measuring the true separation of control and cash flow rights.

${ }^{6}$ http://www.cninfo.com.cn

7 This is a comprehensive database which has been used in other Chinese accounting and corporate governance studies (see., e.g., Wang et al., 2008).
} 
The ownership-control wedge in Chinese firms is highly variable, particularly for those that are privately owned, with an average voting-cash flow rights ratio of 3.232 and a standard deviation of 5.50. With respect to external governance, state firms appear to be more prevalent in provinces with better external legal and regulatory development. The average board consists of approximately ten members with a mean of three independent directors who meet around eight times a year.

\section{Demand for Audit Committees}

We use a logit regression model to investigate the factors that lead firms to use an audit committee.

$$
P(y \mid \mathbf{x})=G(\mathbf{x} \boldsymbol{\beta}) \equiv \exp (\mathbf{x} \boldsymbol{\beta}) /[1+\exp (\mathbf{x} \boldsymbol{\beta})]
$$

where $\mathrm{y}=1$ when a firm has an audit committee and $\mathrm{y}=0$ otherwise; $\mathbf{x}$ is a vector of explanatory variables and $\boldsymbol{\beta}$ is a vector of coefficients to be estimated. To differentiate between private and state ownership, we create a set of interactive variables to incorporate cross-group variance. This is superior to studying subsamples of the data, which can only be valid when the sample error vectors are independent. Variables with a prefix of 'Gov_' are interactive variables, constructed by multiplying 'Gov' (a dummy variable equal to 1 when the state is the largest shareholder and 0 otherwise) with the target variable. These interactive variables are directly related to our hypotheses and capture differences between state and privately controlled firms.

Because there is a high correlation (0.81) between cash flow and voting rights, we use cash flow rights, $(C)$ to measure the level of ownership, and the ratio of voting rights $(V)$ to cash flow rights to capture the ownership-control wedge $(V / C)$. Finally, we include control 
variables for size (Size), fixed asset utilization (FixAssTotAss), and the sample period (year03, year04). The resulting specification of $\mathbf{x}$ in Equation (1) is as follows:

$\mathbf{x}=\left\{G o v, G o v \_C, G o v \_C^{2}, G o v \_V C, G o v \_P y r a m i d, G o v \_D e b t, G o v \_D i r s, C, C^{2}, V C\right.$, Pyramid, Debt, DirS, Big4, BoardSize, BoardInd, Combine, NumBoardMeet, Size, FixAssTotAss, CMI, GDI, LEI, year dummies\}

Apart from their signs, it is not a simple task to directly interpret the coefficients in a logit model. One way, which also facilitates comparison across models, is to consider the partial derivative of the probability that an audit committee exists $(y=1)$ with respect to any continuous explanatory variable, $x_{i}$. This gives the marginal effect of $x_{i}$ on $P(y=1 \mid x)$. The formula is as follows:

$$
\frac{\partial G(\mathbf{x} \boldsymbol{\beta})}{\partial x_{i}}=g(\mathbf{x} \boldsymbol{\beta}) \beta_{i} \equiv \frac{\exp (\mathbf{x} \boldsymbol{\beta})}{[1+\exp (\mathbf{x} \boldsymbol{\beta})]^{2}} \beta_{i}
$$

The effect of a change in $\mathrm{x}_{\mathrm{i}}$ also depends on the other variables in $\mathbf{x}$ through $g(\mathbf{x} \boldsymbol{\beta})$. As in the standard logit model, $g(\mathbf{x} \boldsymbol{\beta}) \equiv \frac{\exp (\mathbf{x} \boldsymbol{\beta})}{[1+\exp (\mathbf{x} \boldsymbol{\beta})]^{2}}$ is always greater than zero, therefore, the sign of the marginal effect of a change in $x_{i}$ corresponds to the sign of its coefficient, $\boldsymbol{\beta}_{\boldsymbol{i}}$. The relative effects of two independent variables, $x_{i}$ and $x_{j}$, do not depend on $\mathbf{x}$ since $\frac{\partial G(\mathbf{x} \boldsymbol{\beta}) / \partial x_{i}}{\partial G(\mathbf{x} \boldsymbol{\beta}) / \partial x_{j}}=\beta_{i} / \beta_{j}$. In this regard, the beta coefficient $\left(\beta_{i}\right)$ is meaningful in relative comparisons.

Unfortunately, the preceding discussion is only valid when the explanatory variables have a linear functional form. If, as is the case with our ownership variable, $C$, there is a quadratic term to capture the nonlinear effect, equation (1) must be rewritten as follows:

$$
P(y \mid \mathbf{x})=G(\mathbf{x} \boldsymbol{\beta}) \equiv G\left(\beta_{0}+\beta_{c, 1} C+\beta_{c, 2} C^{2}+\beta_{1} x_{1} \ldots+\beta_{k} x_{k}\right)
$$


where $C$ is the ownership variable and $x_{i}$ refers to other linear explanatory variables. If we are interested in the partial effect of $C$ on $\mathrm{P}(\mathrm{y})$, it can be evaluated as

$$
\frac{\partial G(\mathbf{x} \boldsymbol{\beta})}{\partial C}=g(\mathbf{x} \boldsymbol{\beta})\left(\beta_{c, 1} C+2 \beta_{c, 2} C\right) \equiv \frac{\exp (\mathbf{x} \boldsymbol{\beta})}{[1+\exp (\mathbf{x} \boldsymbol{\beta})]^{2}}\left(\beta_{c, 1} C+2 \beta_{c, 2} C\right)
$$

In this case, Equation (4) shows that the partial effect of cash flow rights, $C$, on the probability that an audit committee exists, $\mathrm{P}(\mathrm{y}=1)$, will depend on the level of $C$ in addition to other variables, $x_{k}$.

To evaluate equations (2) and (4), the level of $\mathbf{x}$ is required to estimate the value of $g(\mathbf{x} \boldsymbol{\beta})$. The natural choice for this value is the sample mean of each variable. However, adjustments need to be made when there are dummy variables and interactions in the regression equation. In the context of the current analysis, we use dummy variables to separate the effect of state and privately-controlled firms. Instead of taking the mean of the dummy variable, we evaluate the equations separately by setting the dummy variable to 1 and 0 respectively. The interactive terms, (Gov_VC, Gov_Pyramid, Gov_Debt, Gov_DirS), are constructed using the means of the original variables multiplied by the Gov dummy.

We estimate the marginal effect of $C$ for 20 different levels of cash flow rights (ranging from 5 to 100 percent) using equation (4). The standard errors of the marginal effects in equations (2) and (4) are obtained using the delta method (Wooldridge, 2002).

Finally, to test whether there is a difference between the probability that an audit committee will be present in state and privately-controlled firms, we construct the predicted probability that an audit committee will exist for each of the two ownership groups and test for a statistical difference. This is equivalent to testing the significance of the marginal effect of the dummy variable 'Gov' including the effects of the interactive terms (Gov_VC, Gov_Pyramid, Gov_Debt, Gov_DirS). The measure is constructed as follows.

$$
\text { Diff_Gov }=\hat{G}_{G o v}-\hat{G}_{P r i}=G\left(\overline{\mathbf{x}}_{G o v=1} \hat{\boldsymbol{\beta}}\right)-G\left(\overline{\mathbf{x}}_{G o v=0} \hat{\boldsymbol{\beta}}\right)
$$


where $\hat{\boldsymbol{\beta}}$ is a vector of coefficients estimated from equation (2), function $G$ is defined in equation (2) and $\overline{\mathbf{x}}_{G \mathrm{Gov}=1}$ and $\overline{\mathbf{x}}_{G \circ v=0}$ are the sample mean of each variable when the controlling owner is the state $(\mathrm{Gov}=1)$ and private $(\mathrm{Gov}=0)$.

Table 3 reports the maximum likelihood estimation results for equation (3). Many coefficients are statistically significant, with an overall Pseudo $\mathrm{R}^{2}$ of 6 percent. In particular, the non-linear impact of ownership on the probability that an audit committee will exist is clearly illustrated with three interactive variables (gov_C, gov_C $C^{2}$, and $C^{2}$ ) statistically significant.

Insert Table 3 about here

The first hypothesis predicts that privately-owned firms will be more likely to form audit committees at extreme levels of ownership. Figures $1 \mathrm{a}$ and $1 \mathrm{~b}$ summarize the marginal effects and standard errors of the controlling ownership variables, respectively. Figure 1a shows that, for private firms, the marginal effect of controlling ownership on the probability of audit committee formation is negative and then positive as the proportion of cash flow rights increases from zero to one. This is suggestive of a ' $U$ ' shaped relationship between audit committee probability and the cash flow rights of the dominant shareholder in privately owned firms. In contrast, the marginal effect graph for state-owned firms is invariant to cash flow rights. Figure $1 \mathrm{~b}$ show that the marginal effects are statistically indifferent from zero.

Insert Figure 1 about here 
In Figure 2a we present a graph of predicted audit committee probabilities for different levels of the largest shareholder's cash flow rights. The probability function for state-owned firms is distinct from privately-owned firms. Consistent with Figure 1a, audit committees are more likely to be found in privately owned firms when the largest shareholder has either very low or very high cash flow rights. Our results also indicate that, for private firms, Type II (majority-minority shareholder) agency relationships in closely-held firms are more severe than Type I (managers-shareholders) relationships in widely held firms.

Insert Figure 2 about here

Overall, the results support Hypothesis 1 that an audit committee is more likely to exist in firms with ownership levels at the high or low extremes (that is, closely or widely held). For state controlled firms, the demand for an audit committee is invariant to the level of controlling ownership.

\section{Value Relevance of Audit Committees}

To study the valuation effect of audit committees, we adopt a variant of Tobin's Q to capture firm value. We choose a market-based measure of Tobin's $Q$ to measure value because, in China, accounting data may be less reliable (Wei et al., 2005). For example, to maintain listing status, all firms must have a positive return on equity (ROE) and every new issue must have an ROE higher than 6\%. This has led listed companies to have high levels of earnings management (Jian and Wong, 2010) and a relative measure such as Tobin's Q can capture accounting value but also embed it within a market valuation context.

The following empirical specification is used to test our second empirical hypothesis. 


$$
Q=\mathbf{x} \boldsymbol{\beta}
$$

where $\mathrm{Q}$ is the sum of the market value of equity and book value of debt divided by the book value of total assets, and $\mathbf{x}$ is the vector of explanatory variables. The specification of $\mathbf{x}$ is as follows.

$\mathbf{x}=\left\{G o v, G o v \_C, G o v \_C^{2}, G o v \_V C, G o v \_P y r a m i d, G o v \_D e b t, G o v \_D i r S, C, C^{2}, V C\right.$, Pyramid, Debt, DirS, Big4, BoardSize, BoardInd, Combine, NumBoardMeet, Investment, Size, year dummies, Pri_Pd_AC, Gov_Pd_AC, HighAgency_Gov_ac, HighAgency_Pri_ac industry_dummy\}

We specify our empirical model with the following considerations. First, we control for the effect of investment on firm value by introducing capital expenditure as an explanatory variable. Second, we investigate the value relevance of audit committees by including several new variables relating to the interaction between audit committees, ownership identity and high agency costs (HighAgency_Gov_AC,HighAgency_Pri_AC). Specifically, we introduce a new variable, HighAgency, representing widely held and closely held firms where HighAgency is equal to 1 if the voting rights of the controlling shareholder is larger than $70 \%$ or lower than $15 \% .^{8}$

To control for endogeneity between audit committee formation and firm value, we carry out an analysis using two-stage least squares (2SLS) regression. The probability that an audit committee will be present in a firm is estimated using equation (2) in the first stage regression and the predicted value of the audit committee variable for each firm is included in the second stage regression (the Q equation). To further differentiate between private and

\footnotetext{
8 We choose the $15 \%$ and $70 \%$ ownership breakpoints to reflect the Chinese ownership environment. Most firms are closely held in China and so we wanted to introduce as much variability (and capture both sides of the ownership range) to the HighAgency variable. and at the same time ensure maximum statistical power in our tests. Other variable checkpoints were explored but they never captured both low and high levels of ownership as broadly as the $15 \%$ and $70 \%$ thresholds.
} 
state-owned firms, we interact the predicted audit committee probability with the state ownership variable, Gov. Formally they are defined as follows:

$$
\begin{aligned}
& \text { Pri_pd_ac } c_{i, t}=\left\{\begin{array}{c}
G\left(\mathbf{x}_{i, t} \hat{\boldsymbol{\beta}}\right), \text { if } G o v=0 \\
0, \text { if } G o v=1
\end{array}\right. \\
& \text { Gov_pd_ac } c_{i, t}=\left\{\begin{array}{c}
0, \text { if } G o v=0 \\
G\left(\mathbf{x}_{i, t} \hat{\boldsymbol{\beta}}\right), \text { if } G o v=1
\end{array}\right.
\end{aligned}
$$

Where $G\left(\mathbf{x}_{i, t} \hat{\boldsymbol{\beta}}\right)$ is the predicted value for a given firm year obtained from the estimation of equation (2). The sum of the coefficients for these two variables gives the overall effect of audit committee formation on firm value while individually they allow us to examine the possible difference between these two types of firms.

Table 4 reports the 2SLS regression results. In the first model, we consider the impact of audit committees in state and privately controlled firms. The base specification is then extended in model (2) by considering the interactive effect of agency costs through HighAgency_Gov_AC and HighAgency_Pri_AC. In model (1), the coefficient on the Gov_ $A C$ variable is positive and statistically significant at the $10 \%$ level, whereas Pri_AC is not significant.

The results from Model (1) shows that audit committees are value relevant and have different implications for firms depending on the identity of the dominant shareholder. However, Model (1) does not consider the impact of audit committees on firms with severe agency issues, which is central to Hypothesis 2. Accordingly, we present further results in Table 4, Model (2), where it can be seen that audit committees are most value relevant when firms have severe agency relationships (i.e. have concentrated or dispersed ownership structures). Both HighAgency_Gov_AC and HighAgency_Pri_pd_AC are positive and significant at the $5 \%$ level and not significantly different from each other. 
In summary, the preceding results partially support our second hypothesis that audit committees are value relevant especially in firms with exacerbated agency relationships. Although we predict that audit committees will have greater value relevance in private firms with dispersed and concentrated ownership structures, our tests show that they are equally important for state-owned firms. In fact, there is some evidence that audit committees have a stronger impact on state-owned firms (Model 1), although this admittedly disappears once the agency costs of ownership are incorporated into the analysis.

\section{Subsidiary Results}

We now consider the remaining hypotheses relating to the impact of audit committees on the agency costs of ownership. The central results are reported in Table 5 where the marginal effects from the logit analysis of Table 3 are extracted and examined. Specifically, we consider the expected instantaneous change in the probability that an audit committee exists for every change in each underlying variable, holding the remaining variables constant. Standard errors and p-values are reported to highlight statistical significance.

\section{Insert Table 5 about here}

Hypothesis 3 predicts that firms with a difference between controlling owner cash and control rights (an ownership-control wedge) will be more likely to use audit committees. This is to reduce the agency costs resulting from the specific ownership structure, and signal to external investors that the firm is serious about transparency and accountability. From Table 5, state-controlled firms with an ownership-control wedge are more likely to form an 
audit committee. There is no evidence that the same pressure is present in firms with private owners.

Drawing on Scharfstein and Stein (2000), Bae et al. (2002) and Fan et al. (2005), Hypothesis 4 predicts that privately owned firms with pyramid control chains are more likely to need audit committees than comparable state-owned firms. We find no evidence of a relationship between pyramid control structures and the presence of audit committees. Although the signs of the Pyramid and Gov_Pyramid variables are consistent with our null hypothesis, the lack of statistical significance in either variable makes them difficult to interpret.

We next consider whether audit committees substitute for firm-level corporate governance structures or whether they act as a complement to improve overall transparency and accountability. Table 5 clearly shows that audit committees are more likely to be present in companies that have other strong governance characteristics. Firms with larger boards, more independent directors, a single individual with joint CEO-chairman responsibilities, and frequent board meetings have a significantly higher probability of having an audit committee.

Finally, we consider whether audit committees will be more prevalent in regions with a poor external governance environment. If audit committees are used to strengthen investor protection in geographical regions with weak regulatory environments, one would expect to see a negative marginal effect in our three macro-governance variables, CMI, GDI and LEI. On the other hand, if audit committees are an expected component of good governance and well-governed firms are more common in strong regulatory environments, a positive marginal effect would be recorded.

The results in Table 5 are somewhat mixed. Whereas the Legal Environment Index (LEI) has a highly significant negative marginal effect, the other two variables are insignificant. In the context of the present study, credit market development and government 
decentralization may have less relevance than the strength of the external legal environment. Our results show that firms will use an audit committee in environments where external legal protection is poorer, which suggests that they are a signaling mechanism to offset weaker external investor protection.

\section{Robustness Tests}

The pooled regressions with year dummies show that audit committees are becoming more common in Chinese firms over time. We also perform a sub-sample analysis for each year of the sample and the results are consistent with our findings for the full period, although the effect of the explanatory variables is less significant in general for the sub-sample analysis.

We apply alternative specifications of the regression equations by replacing cash flow rights with voting rights as a measure of controlling ownership. The results are very similar to what has already been reported in the main results section. The only difference is that the turning point of the nonlinear effect for voting rights is about 5 percent higher than that of cash flow rights. This is to be expected, since, for a given firm, the ultimate controlling shareholder's voting rights must be greater or equal to their cash flow rights.

We also examine the robustness of our results to alternative measures of separation in voting and cash flow rights. The overall results are the same.

\section{CONCLUSIONS}

The quality of financial reporting and the auditing of financial reports is at the heart of good governance. Since, audit committees are responsible for monitoring a firm's internal audit function and its relations with the external auditor, their significance should be directly linked to the importance of financial reporting to the firm's main stakeholders. Audit committees 
will only add value when the benefits from their existence outweigh the costs of not having them.

The Chinese corporate environment is a particularly useful laboratory for investigating the interaction between audit committees and ownership structure because of the heterogeneous spread of shareholders across the public and private sector and the developing state of corporate governance in the region. Unlike most developed economies, audit committees are not obligatory for Chinese stock exchange listing. We are thus able to explore the role of audit committees in firms and whether their importance and prevalence is related to the ultimate controlling shareholder.

We find that in China, contrasting shareholder objectives influence the need for an audit committee. Firms with severe agency relationships are likely to have an audit committee and this is more pronounced when the firm is widely held or has a concentrated ownership structure. The contrasting objectives of state and private shareholders lead to divergent corporate objectives and this is evidenced by the different likelihoods of audit committees being used in firms across ownership concentration.

Privately owned firms are significantly more likely to have an audit committee when the controlling shareholder has concentrated shareholdings, whereas state-owned firms use audit committees when there is an ownership-control wedge. Audit committees are more common in firms with better governance structures and in regions where the external legal framework is weak. Finally, audit committees are value relevant particularly for ownership structures that are associated with high agency costs (widely-held and closely-held firms), irrespective of the ultimate controlling owner identity.

This study contributes to the literature on audit committees by investigating their effectiveness under different agency conditions within a firm. We show that the priorities of the largest shareholder (state or private) can influence the implementation of structures that 
ostensibly improve value but are not necessarily consistent with the shareholder's objectives. We also present evidence that audit committees are valued by investors and ultimately improve the agency relationships among controlling owners, minority shareholders and firm management. 


\section{REFERENCES}

Abbott, L. J., Parker, S., Peters, G. F., and K. Raghunandan, (2003), 'An Empirical Investigation Of Audit Fees, Nonaudit Fees, And Audit Committees', Contemporary Accounting Research, Vol 20, pp. 215-234.

Abbott, L. J., Parker, S., Peters, G. F., and D.V. Rama, (2007), 'Corporate Governance, Audit Quality, And The Sarbanes-Oxley Act: Evidence From Internal Audit Outsourcing', Accounting Review, Vol. 82.

Ali, A., Chen, T. Y., and S. Radhakrishnan, (2007), 'Corporate Disclosures By Family Firms’, Journal Of Accounting And Economics, Vol. 44, pp. 238-286.

Archambeault, D. S., Dezoort, F. T., and D. Hermanson, (2008), ‘Audit Committee Incentive Compensation And Accounting Restatements’, Contemporary Accounting Research, Vol. 25, pp. 965-998.

Bae, K. H., Kang, J. K., and J.M. Kim, (2002), ‘Tunneling Or Value Added? Evidence From Mergers By Korean Business Groups’, Journal of Finance, Vol. 57, pp. 2695-2740.

Bae, K. H., Baek, J. S., Kang, J. K., and W.L. Liu, (2012), 'Do Controlling Shareholders’ Expropriation Incentives Imply A Link Between Corporate Governance And Firm Value? Theory And Evidence', Journal of Financial Economics, Vol. 105, pp.412435.

Ball, R., Kothari, S. P., and A. Robin, (2000), 'The Effect Of International Institutional Factors On Properties Of Accounting Earnings', Journal of Accounting and Economics, Vol. 29, pp. 1-51.

Beasley, M. S., Carcello, J. V., Hermanson, D. R., and T.L. Neal, (2009), 'The Audit Committee Oversight Process’, Contemporary Accounting Research, Vol. 26, pp. 65104. 
Boubakri, N., Cosset, J-C., and W. Saffar, (2013), The Role Of State And Foreign Owners In Corporate Risk-Taking: Evidence From Privatization', Journal of Financial Economics, Vol. 108, No. 3, pp. 641-658.

Boycko, M., Shleifer, A., and R.W. Vishny, (1996), ‘A Theory Of Privatisation', The Economic Journal, Vol. 106, pp. 309-319.

Bushman, R. M., Piotroski, J. D., and A.J. Smith, (2004), 'What Determines Corporate Transparency?’, Journal of Accounting Research, Vol. 42, pp. 207-252.

Bushman, R. M., and A.J. Smith, (2001), 'Financial Accounting Information And Corporate Governance’, Journal of Accounting and Economics, Vol. 32, pp. 237-333.

Carcello, J. V., and T.L. Neal, (2003), 'Audit Committee Characteristics And Auditor Dismissals Following "New" Going-Concern Reports’, Accounting Review, Vol. 78, pp. 95-117.

Caskey, J., Nagar, V., and P. Petacchi, (2010), 'Reporting Bias With An Audit Committee', Accounting Review, Vol. 85, pp. 447-481.

Chang, E. C., and S.M.L. Wong, (2009), 'Governance With Multiple Objectives: Evidence From Top Executive Turnover In China', Journal of Corporate Finance, Vol. 15, pp. 230-244.

Chen, K. Y., and J. Zhou, (2007), 'Audit Committee, Board Characteristics, And Auditor Switch Decisions By Andersen's Clients’, Contemporary Accounting Research, Vol. 24, pp. 1085-1121.

Chen, S., Sun, Z., Tang, S., \& D. Wu, (2011), 'Government Intervention And Investment Efficiency: Evidence From China’, Journal of Corporate Finance, Vol. 17, No. 2, pp. 259-271. 
Claessens, S., Djankov, S., Fan, J. R. H., and L.H.P. Lang, (2002), 'Disentangling The Incentive And Entrenchment Effects Of Large Shareholdings', Journal of Finance, Vol. 57, pp. 2741-2771.

Dahya, J., Dimitrov, O., and J.J., McConnell, (2008), 'Dominant Shareholders, Corporate Boards, And Corporate Value: A Cross-Country Analysis', Journal of Financial Economics, Vol. 87, pp. 73-100.

Defond, M. L., Hann, R. N., and X.S. Hu, (2005), 'Does The Market Value Financial Expertise On Audit Committees Of Boards Of Directors?' Journal of Accounting Research, Vol. 43, pp. 153-193.

Dewenter, K. L., and P.H. Malatesta, (2001), ‘State-Owned And Privately Owned Firms: An Empirical Analysis Of Profitability, Leverage, And Labor Intensity’, American Economic Review, Vol. 91, pp. 320-334.

Engel, E., Hayes, R. M., and X. Wang, (2010), 'Audit Committee Compensation And The Demand For Monitoring Of The Financial Reporting Process’, Journal of Accounting and Economics, Vol. 49, pp. 136-154.

Faccio, M., (2006), ‘Politically Connected Firms’, American Economic Review, Vol. 96, pp. 369-386.

Faccio, M., and L.H.P. Lang, (2002), 'The Ultimate Ownership Of Western European Corporations’, Journal of Financial Economics, Vol. 65, pp. 365-395.

Fan, J.P.H., and T.J. Wong, (2002), 'Corporate Ownership Structure And The Informativeness Of Accounting Earnings In East Asia', Journal of Accounting and Economics, Vol. 33, pp. 401-425.

Fan, J.P.H., and T.J. Wong, (2005), 'Do External Auditors Perform A Corporate Governance Role In Emerging Markets? Evidence From East Asia', Journal of Accounting Research, Vol. 43, pp. 35-72. 
Fan, J. P. H., Wong, T. J., and T.Y. Zhang, (2005) 'The Emergence Of Corporate Pyramides In China’, Mimeo. Chinese Univeristy of Hong Kong.

Fan, J. P. H., Wei, K. C. J., and X. Xu, (2011), 'Corporate Finance And Governance In Emerging Markets: A Selective Review And An Agenda For Future Research', Journal of Corporate Finance, Vol. 17, pp. 207-214.

Gaynor, L. M., McDaniel, L. S., and T.L. Neal, (2006), 'The Effects Of Joint Provision And Disclosure Of Nonaudit Services On Audit Committee Members’ Decisions And Investors’ Preferences’, Accounting Review, Vol. 81, pp. 873-896.

Ghosh, A., Marra, A., and D. Moon, (2010), 'Corporate Boards, Audit Committees, And Earnings Management: Pre- And Post-SOX Evidence', Journal of Business Finance and Accounting, Vol. 37, pp. 1145-1176.

Goh, B. W., (2009), ‘Audit Committees, Boards Of Directors, And Remediation Of Material Weaknesses In Internal Control’, Contemporary Accounting Research, Vol. 26, pp. 549-571.

Grossman, S. J., and O.D. Hart, (1988), 'One Share One Vote And The Market For Corporate-Control’, Journal of Financial Economics, Vol. 20, pp. 175-202.

Huyghebaert, N. and L. Wang, (2012), 'Expropriation Of Minority Investors In Chinese Listed Firms: The Role Of Internal And External Corporate Governance Mechanisms’, Corporate Governance: An International Review, Vol. 20, pp. 308332.

Harris, M., and A. Raviv, (1988), 'Corporate-Control Contests And Capital Structure', Journal of Financial Economics, Vol. 20, pp. 55-86.

Hoitash, U., Hoitash, R., and J.C. Bedard, (2009), 'Corporate Governance And Internal Control Over Financial Reporting: A Comparison Of Regulatory Regimes', Accounting Review, Vol. 84, pp. 839-867. 
Jensen, M. C., and W.H. Meckling, (1976), 'Theory Of Firm - Managerial Behavior, Agency Costs And Ownership Structure’, Journal of Financial Economics, Vol. 3, pp. 305360.

Jian, M., and T.J. Wong, (2010), 'Propping Through Related Party Transactions', Review of Accounting Studies, Vol. 15, pp. 70-105.

Johnson, S., and T. Mitton, (2003), 'Cronyism And Capital Controls: Evidence From Malaysia', Journal of Financial Economics, Vol. 67, pp. 351-382.

Klein, A., (2002), 'Audit Committee, Board Of Director Characteristics, And Earnings Management', Journal of Accounting and Economics, Vol. 33, pp. 375-400.

Krishnan, G. V., and G. Visvanathan, (2008), 'Does The SOX Definition Of An Accounting Expert Matter? The Association Between Audit Committee Directors, Accounting Expertise And Accounting Conservatism’, Contemporary Accounting Research, Vol. 25, pp. 827-858.

Krishnan, J., (2005), 'Audit Committee Quality And Internal Control: An Empirical Analysis’, Accounting Review, Vol. 80, pp. 649-675.

La Porta, R., Lopez-de-Silanes, F., and A. Shleifer, (1999), 'Corporate Ownership Around The World', Journal of Finance, Vol. 54, pp. 471-517.

Lemmon, M. L., and K.V. Lins, (2003), ‘Ownership Structure, Corporate Governance, And Firm Value: Evidence From The East Asian Financial Crisis’, Journal of Finance, Vol. 58, pp. 1445-1468.

Lennox, C. S., and C.W. Park, (2007), 'Audit Firm Appointments, Audit Firm Alumni, And Audit Committee Independence', Contemporary Accounting Research, Vol. 24, pp. 235-257. 
Leuz, C., and F. Oberholzer-Gee, (2006), 'Political Relationships, Global Financing, And Corporate Transparency: Evidence From Indonesia’, Journal of Financial Economics, Vol. 81, pp. 411-439.

Liu, G., and G. Tian, (2012), 'Controlling Shareholder, Expropriations And Firm's Leverage Decision: Evidence From Chinese Non-Tradable Share Reform’, Journal of Corporate Finance, Vol. 18, pp. 782-803.

Magilke, M. J., Mayhew, B. W., and J.E. Pike, (2009), 'Are Independent Audit Committee Members Objective? Experimental Evidence', Accounting Review, Vol. 84, pp. 1959-1981.

Naiker, V., and D.S. Sharma, (2009), 'Former Audit Partners On The Audit Committee And Internal Control Deficiencies’, Accounting Review, Vol. 84, pp. 559-587.

Price, R., Román, F. J., and B. Rountree, (2011), 'The Impact Of Governance Reform On Performance And Transparency’, Journal of Financial Economics, Vol. 99, No. 1, pp. 76-96.

Scharfstein, D. S., and J.C. Stein, (2000), 'The Dark Side Of Internal Capital Markets: Divisional Rent-Seeking And Inefficient Investment', Journal of Finance, Vol. 55, pp. 2537-2564.

Shleifer, A., (1998), ‘State Versus Private Ownership’, Journal of Economic Perspectives, Vol. 12, pp. 133-150.

Shleifer, A., and R.W. Vishny, (1994), 'Politicians and Firms', Quarterly Journal of Economics, Vol. 109, pp. 995-1025.

Vafeas, N., (2005), ‘Audit Committees, Boards, And The Quality Of Reported Earnings’, Contemporary Accounting Research, Vol. 22, pp. 1093-1122. 
Wang, Q., Wong, T. J., and L.J. Xia, (2008), 'State Ownership, The Institutional Environment, And Auditor Choice: Evidence From China', Journal of Accounting and Economics, Vol. 46, pp. 112-134.

Wei, Z., Xie, F., and S. Zhang, (2005), 'Ownership Structure And Firm Value In China's Privatized Firms:1991-2001', Journal of Financial and Quantitative Analysis, Vol. 40, pp. 87-108.

Wooldridge, J. M., (2002), ‘Introductory Econometrics : A Modern Approach’ (Mason).

Xie, B., Davidson, W. N., and P.J. DaDalt, (2003), 'Earnings Management And Corporate Governance: The Role Of The Board And The Audit Committee', Journal of Corporate Finance, Vol. 9, pp. 295-316. 


\begin{tabular}{|c|c|}
\hline Variable & Definition \\
\hline $\mathrm{AC}$ & $\begin{array}{l}\text { A dummy variable that is equal to } 1 \text { when an audit committee exists } \\
\text { during the reporting year and } 0 \text { otherwise. }\end{array}$ \\
\hline Q & $\begin{array}{l}\text { Tobin's Q calculated as (market value of equity + book value of debt)/ } \\
\text { total assets. }\end{array}$ \\
\hline Gov & $\begin{array}{l}\text { A dummy variable that is equal to } 1 \text { if the ultimate largest shareholder } \\
\text { of the company is the state and } 0 \text { otherwise. }\end{array}$ \\
\hline V & Proportion of voting rights of the largest shareholder \\
\hline $\mathrm{C}$ & Proportion of cash flow rights of the largest shareholder \\
\hline V_C & Voting rights less cash flow rights \\
\hline$\overline{\mathrm{VC}}$ & Voting rights divided by cash flow rights \\
\hline HighAgency & $\begin{array}{l}\text { A dummy variable that is equal to } 1 \text { if the percentage voting rights of } \\
\text { the largest shareholder is higher than } 70 \% \text { or lower than } 15 \% \text {. }\end{array}$ \\
\hline Pyramid & Length of pyramidal chain \\
\hline Debt & Total debt over total assets \\
\hline DirS & Proportionate director shareholdings in firm \\
\hline Big4 & $\begin{array}{l}\text { A dummy variable that is equal to } 1 \text { when the company's auditor is one } \\
\text { of the big } 4 \text { accountancy firms and } 0 \text { otherwise. }\end{array}$ \\
\hline BoardSize & The total number of directors on the board. \\
\hline BoardInd & The proportion of independent directors on the board. \\
\hline Combine & $\begin{array}{l}\text { A dummy variable that is equal to } 1 \text { when the Role of CEO and } \\
\text { Chairman is combined and } 0 \text { otherwise. }\end{array}$ \\
\hline NumBoardMeet & The number of board meetings in a year \\
\hline Investment & The natural logarithm of Capital Expenditure \\
\hline Size & The natural Logarithm of Total assets \\
\hline FixAssTotAss & Total fixed assets over total assets \\
\hline CMI & $\begin{array}{l}\text { The credit market index measures the percentage of deposits taken by } \\
\text { non-state financial institutions and the percentage of short-term loans } \\
\text { to the non-state sector for each province or provincial level region in } \\
2000 \text {. }\end{array}$ \\
\hline GDI & $\begin{array}{l}\text { The government decentralization index is based on government } \\
\text { spending as a percentage of GDP, the tax rates in a province, and the } \\
\text { amount of government administrative regulations for each province in } \\
\text { 2000. A higher index suggests less government involvement. }\end{array}$ \\
\hline LEI & $\begin{array}{l}\text { The legal environment index measured by the number of lawyers as a } \\
\text { percentage of the population, the efficiency of the local courts and } \\
\text { protection of property rights, for each province or provincial level } \\
\text { region in } 2000 \text {. }\end{array}$ \\
\hline
\end{tabular}

This table summarizes the definitions of variables used in the analysis. All variables are collected by the authors except CMI, GDI and LEI, which is taken from Fan, G., Wang, X., 2003. The Report on the Relative Process of Marketization of Each Region in China. The Economic Science Press (in Chinese). 


\begin{tabular}{lrrrr}
\hline & Private & State & \multicolumn{2}{c}{ Difference } \\
Tobin's Q & 2.057 & 1.928 & 0.129 & $* * *$ \\
Voting Rights of Largest Shareholder (V) & 0.361 & 0.472 & -0.111 & $* * *$ \\
Cash Flow Rights of Largest Shareholder (C) & 0.211 & 0.426 & -0.215 & $* * *$ \\
Voting Rights - Cash Flow Rights (V_C) & 0.150 & 0.046 & 0.104 & $* * *$ \\
Voting Rights/Cash Flow Rights (VC) & 3.232 & 1.342 & 1.890 & $* * *$ \\
Length of Pyramid Chain (Pyramid) & 2.434 & 2.300 & 0.134 & $* * *$ \\
Total Debt/Total Assets (Debt) & 0.500 & 0.460 & 0.040 & $* * *$ \\
Director Shareholdings (DirS) & 0.018 & 0.001 & 0.017 & $* * *$ \\
Big 4 Auditor Dummy (Big4) & 0.037 & 0.052 & -0.015 & $*$ \\
Number of Directors (BoardSize) & 9.302 & 10.115 & -0.813 & $* * *$ \\
Proportion of Independent Directors (BoardInd) & 0.318 & 0.298 & 0.020 & $* * *$ \\
Combined CEO/Chair Dummy (Combine) & 0.147 & 0.091 & 0.057 & $* * *$ \\
Number of Board Meetings per annum (NumBoardMeet) & 8.265 & 7.483 & 0.782 & $* * *$ \\
Ln(Total Assets) (Size) & 1.477 & 2.647 & -1.170 & $* * *$ \\
Total Fixed Assets/Total Assets (FixAssTotAss) & 0.316 & 0.376 & -0.060 & $* * *$ \\
Credit Market Index (CMI) & 5.069 & 5.115 & -0.047 & \\
Government Decentralization Index (GDI) & 6.621 & 6.508 & 0.113 & $* *$ \\
Legal Environment Index (LEI) & 5.455 & 5.624 & -0.169 & $* * *$ \\
\hline
\end{tabular}

This table reports the descriptive statistics of the variables by ownership type. There 294 (778) private (state) firms in the sample leading to $882(2,334)$ firm-year observations over the sample period 2002 to 2004 . Each variable is defined in Table 1. This table reports the mean of the measurements.

$* \mathrm{p}<.10$
$* * \mathrm{p}<.05$
$* * * \mathrm{p}<.01$ 
Table 3 - Probability of Audit Committee in a Firm

\begin{tabular}{lrrc}
\hline Variables & Coef. & Std.Err. & $\mathbf{Z}$ \\
\hline Gov & -0.165 & 0.555 & -0.30 \\
Gov_C & 3.917 & 2.040 & $1.922^{*}$ \\
Gov C & -5.758 & 2.592 & $-2.22^{* *}$ \\
Gov VC & 0.062 & 0.041 & 1.52 \\
Gov Pyramid & -0.133 & 0.118 & -1.13 \\
Gov Debt & 0.306 & 0.485 & 0.63 \\
Gov DirS & 2.090 & 2.416 & 0.87 \\
\hline C & -2.357 & 1.573 & -1.50 \\
C & 4.065 & 2.152 & $1.89 *$ \\
VC & 0.007 & 0.016 & 0.46 \\
Pyramid & 0.103 & 0.098 & 1.05 \\
Debt & -0.226 & 0.420 & -0.54 \\
DirS & -0.031 & 0.665 & -0.05 \\
\hline Big4 & -0.001 & 0.183 & 0.00 \\
Boardsize & 0.105 & 0.018 & $5.67 * * *$ \\
BoardInd & 5.166 & 0.597 & $8.666^{* * *}$ \\
Combine & 0.362 & 0.147 & $2.47 * *$ \\
NumBoardMeet & 0.055 & 0.013 & $4.38 * * *$ \\
Size & 0.034 & 0.050 & 0.67 \\
FixAsTTotAss & 0.189 & 0.202 & 0.94 \\
\hline CMI & -0.009 & 0.020 & -0.45 \\
GDI & 0.053 & 0.034 & 1.56 \\
LEI & -0.184 & 0.032 & $-5.84 * * *$ \\
\hline year03 & 0.215 & 0.109 & $1.98 * *$ \\
year04 & 0.568 & 0.110 & $5.16 * * *$ \\
Intercepts & -4.030 & 1.122 & $-3.59 * * *$ \\
Log likelihood & -2030.115 & & Pseudo $\mathrm{R}^{2} 6.48 \%$ \\
\hline
\end{tabular}

This table reports the estimation coefficients of the following logit model.

$$
P(y \mid \mathbf{x})=G(\mathbf{x} \boldsymbol{\beta}) \equiv \exp (\mathbf{x} \boldsymbol{\beta}) /[1+\exp (\mathbf{x} \boldsymbol{\beta})]
$$

where $\mathrm{y}=1$ when an audit committee exists in a firm and $\mathrm{y}=0$ otherwise and $\mathbf{x}=\{G o v$, Gov_C, Gov_C ${ }^{2}$,Gov_VC, Gov_Pyramid, Gov_Debt, Gov_DirS, C, C ${ }^{2}$, VC, Pyramid, Debt, DirS, Big4, BoardSize, BoardInd, Combine, NumBoardMeet, Size, FixAssTotAss, CMI, GDI, LEI, year dummies\}. The estimated coefficient (Coef.), Standard Error (Std.Err.) and $\mathrm{z}$ Statistics are reported.

$* \mathrm{p}<.10$
$* * \mathrm{p}<.05$
$* * * \mathrm{p}<.01$ 
Table 4 - 2SLS Estimation Results for Firm Value

\begin{tabular}{|c|c|c|c|c|c|c|}
\hline \multirow[b]{2}{*}{ Gov } & \multicolumn{3}{|c|}{ Model (1) } & \multicolumn{3}{|c|}{ Model (2) } \\
\hline & -0.110 & $(-1.18)$ & & -0.097 & $(-1.02)$ & \\
\hline Gov_C & 0.118 & $(0.37)$ & & 0.009 & $(0.03)$ & \\
\hline Gov_C $C^{2}$ & -0.126 & $(-0.31)$ & & 0.125 & $(0.27)$ & \\
\hline Gov_VC & -0.010 & $(-1.72)$ & $*$ & -0.011 & $(-1.81)$ & $*$ \\
\hline Gov_Pyramid & 0.067 & $(3.60)$ & $* * *$ & 0.062 & $(3.36)$ & $* * *$ \\
\hline Gov_Debt & -0.078 & $(-1.01)$ & & -0.069 & $(-0.90)$ & \\
\hline Gov_DirS & 0.078 & $(0.21)$ & & 0.090 & $(0.24)$ & \\
\hline $\mathrm{C}^{-}$ & -0.411 & $(-1.67)$ & $*$ & -0.162 & $(-0.60)$ & \\
\hline$C^{2}$ & 0.387 & $(1.15)$ & & -0.055 & $(-0.14)$ & \\
\hline $\mathrm{VC}$ & 0.000 & $(-0.07)$ & & 0.001 & $(0.35)$ & \\
\hline Pyramid & -0.001 & $(-0.03)$ & & 0.003 & $(0.21)$ & \\
\hline Debt & -0.122 & $(-1.85)$ & $*$ & -0.124 & $(-1.88)$ & $*$ \\
\hline DirS & -0.061 & $(-0.54)$ & & -0.059 & $(-0.52)$ & \\
\hline Investment & 0.006 & $(1.37)$ & & 0.007 & $(1.51)$ & \\
\hline Size & -0.206 & $(-20.78)$ & $* * *$ & -0.210 & $(-21.00)$ & $* * *$ \\
\hline FixAssTotAss & -0.029 & $(-0.76)$ & & -0.030 & $(-0.79)$ & \\
\hline CMI & 0.004 & $(1.23)$ & & 0.004 & $(1.28)$ & \\
\hline GDI & 0.003 & $(0.60)$ & & 0.003 & $(0.60)$ & \\
\hline LEI & 0.015 & (2.79) & $* * *$ & 0.015 & $(2.80)$ & $* * *$ \\
\hline Gov_AC & 0.124 & (1.77) & $*$ & 0.104 & (1.48) & \\
\hline Pri_AC & 0.063 & $(0.63)$ & & 0.034 & $(0.34)$ & \\
\hline HighAgency_Gov_AC & & & & 0.129 & $(2.14)$ & $* *$ \\
\hline HighAgency_Pri_AC & & & & 0.278 & $(2.36)$ & $* *$ \\
\hline Intercept & 5.691 & (31.03) & $* * *$ & 5.724 & (31.08) & $* * *$ \\
\hline Year03 & -0.145 & $(-8.51)$ & $* * *$ & -0.143 & $(-8.43)$ & $* * *$ \\
\hline Year04 & -0.260 & $(-12.65)$ & $* * *$ & -0.257 & $(-12.52)$ & $* * *$ \\
\hline Adj R-Sq & 0.314 & & & 0.314 & & \\
\hline
\end{tabular}

This table reports the 2SLS Estimation Results for firm value (Q). The following specification of the model is estimated.

$$
Q=\mathbf{x} \boldsymbol{\beta} \quad(2)
$$

where $\mathbf{x}=\left\{G o v, G o v \_C, G o v \_C^{2}, G o v \_V C, G o v \_P y r a m i d, G o v \_D e b t, G o v \_D i r S, C, C^{2}\right.$, VC, Pyramid, Debt, DirS, Big4, BoardSize, BoardInd, Combine, NumBoardMeet, Investment, Size, year dummies, Pri_Pd_AC, Gov_Pd_AC, HighAgency_Gov_ac, HighAgency_Pri_ac industry_dummy\}

The figures in parenthesis are t-values. Model (2) is the same as model (1) except for the inclusion of the interactive agency cost-ownership-audit committee variables.

$* \mathrm{p}<.10$
$* * \mathrm{p}<.05$
$* * * \mathrm{p}<.01$ 
Table 5 - Marginal Effects and Standard Errors of the Logit Model

\begin{tabular}{lrrrl}
\hline Variables & $\begin{array}{r}\text { Marginal } \\
\text { Effects }\end{array}$ & $\begin{array}{r}\text { Std. } \\
\text { Err }\end{array}$ & $\mathbf{z}$ & \\
\hline DirS & -0.007 & 0.156 & -0.050 & \\
VC & 0.002 & 0.004 & 0.460 & \\
Pyramid & 0.024 & 0.023 & 1.050 & \\
Debt & -0.053 & 0.099 & -0.540 & \\
\hline Gov_DirS & 0.502 & 0.605 & 0.830 & \\
Gov_VC & 0.017 & 0.009 & 1.850 & $*$ \\
Gov_Pyramid & -0.007 & 0.016 & -0.460 & \\
Gov_Debt & 0.020 & 0.063 & 0.310 & \\
\hline Big4 & 0.000 & 0.043 & 0.000 & \\
BordSize & 0.025 & 0.004 & 5.670 & $* * *$ \\
BoardInd & 1.212 & 0.140 & 8.660 & $* * *$ \\
Combine & 0.085 & 0.034 & 2.470 & $* *$ \\
NumBoardMeet & 0.013 & 0.003 & 4.380 & $* * *$ \\
Size & 0.008 & 0.012 & 0.670 & \\
FixAssTotAss & 0.044 & 0.047 & 0.940 & \\
CMI & -0.002 & 0.005 & -0.450 & \\
GDI & 0.012 & 0.008 & 1.560 & \\
LEI & -0.043 & 0.007 & -5.840 & $* * *$ \\
\hline
\end{tabular}

This Table reports the post estimation tests of the audit committee formation logit model. The marginal effects and standard errors of the linear explanatory variables $\left(x_{i}\right)$ are evaluated by

$$
\frac{\partial G(\overline{\mathbf{x}} \hat{\boldsymbol{\beta}})}{\partial x_{i}}=g(\overline{\mathbf{x}} \hat{\boldsymbol{\beta}}) \hat{\beta}_{i}=\frac{\exp (\overline{\mathbf{x}} \hat{\boldsymbol{\beta}})}{[1+\exp (\overline{\mathbf{x}} \hat{\boldsymbol{\beta}})]^{2}} \hat{\beta}_{i}
$$

Where $\hat{\boldsymbol{\beta}}$ is a vector of coefficients estimated from [1]; and $\overline{\mathbf{x}}$ is a vector of means of the explanatory variables. Marginal effects for the privately (state) controlled companies are evaluated at the mean of all explanatory variables setting gov $=0($ gov $=1) . \mathrm{Z}$ and $\mathrm{p}>|\mathrm{z}|$ columns report the test statistics and the p-value.

$* \mathrm{p}<.10$

$* * \mathrm{p}<.05$

$* * * \mathrm{p}<.01$ 
Figure 1 - Marginal Effects of Cash Flow Rights on the Probability of Audit Committee Formation

Figure 1a Privately Controlled Firms

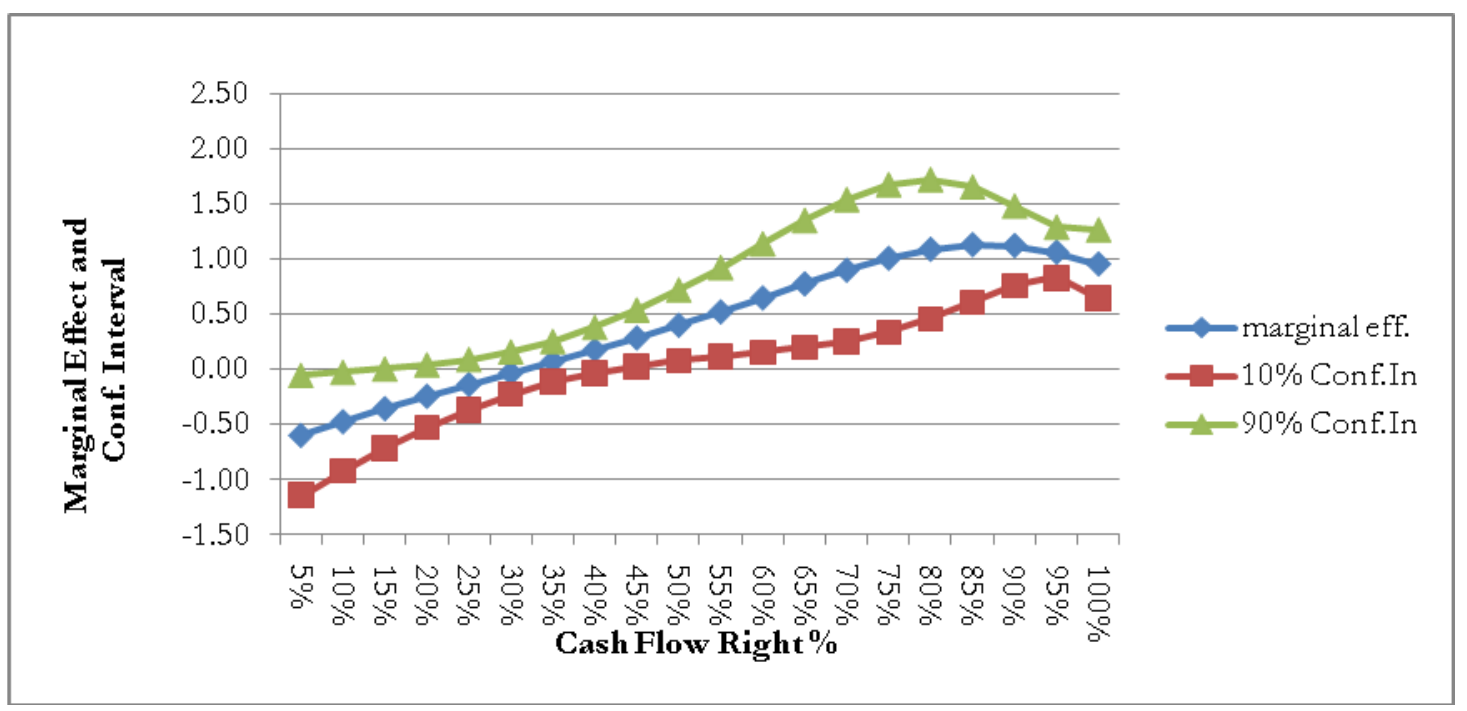

Figure 1b State Controlled Firms

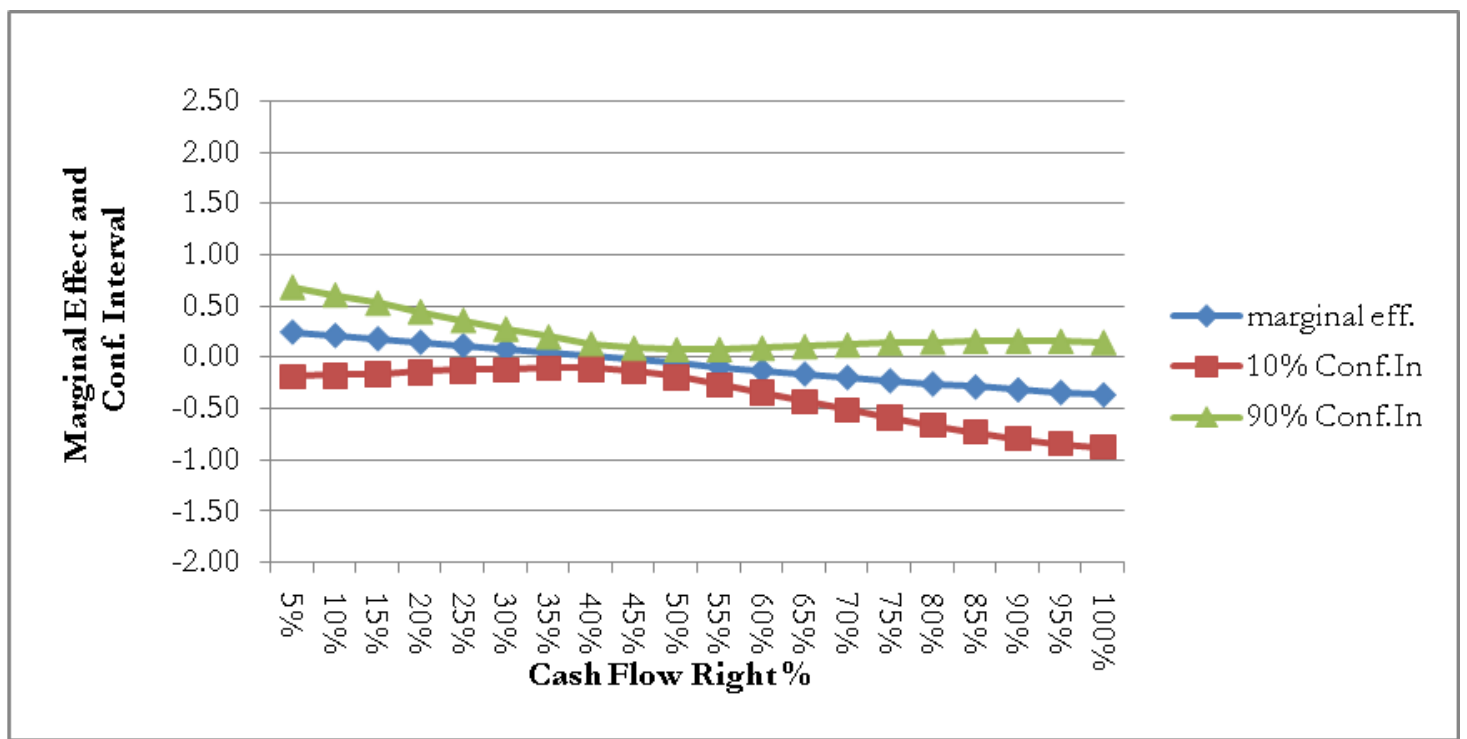

This figure reports the marginal effects and confidence interval for the cash flow rights on the probability of audit committee formation.

$$
\frac{\partial G(\mathbf{x} \boldsymbol{\beta})}{\partial x_{1}}=g(\mathbf{x} \boldsymbol{\beta})\left(\beta_{1,1}+2 \beta_{1,2} x_{1}\right) \equiv \frac{\exp (\mathbf{x} \boldsymbol{\beta})}{[1+\exp (\mathbf{x} \boldsymbol{\beta})]^{2}}\left(\beta_{1,1}+2 \beta_{1,2} x_{1}\right)
$$

Marginal effects for private (state) controlled firms are evaluated at the mean of all explanatory variables setting $g o v=0(g o v=1)$. Different levels of cash flow rights are tested by varying cash flow rights (C) from 5 percent to 100 percent in 5 percent intervals. 
Figure 2 - Predicted Probability of Audit Committees in Private and State Controlled Firms

Figure 2a Predicted Probability that an Audit Committee will exist for State and Privately Controlled Firms

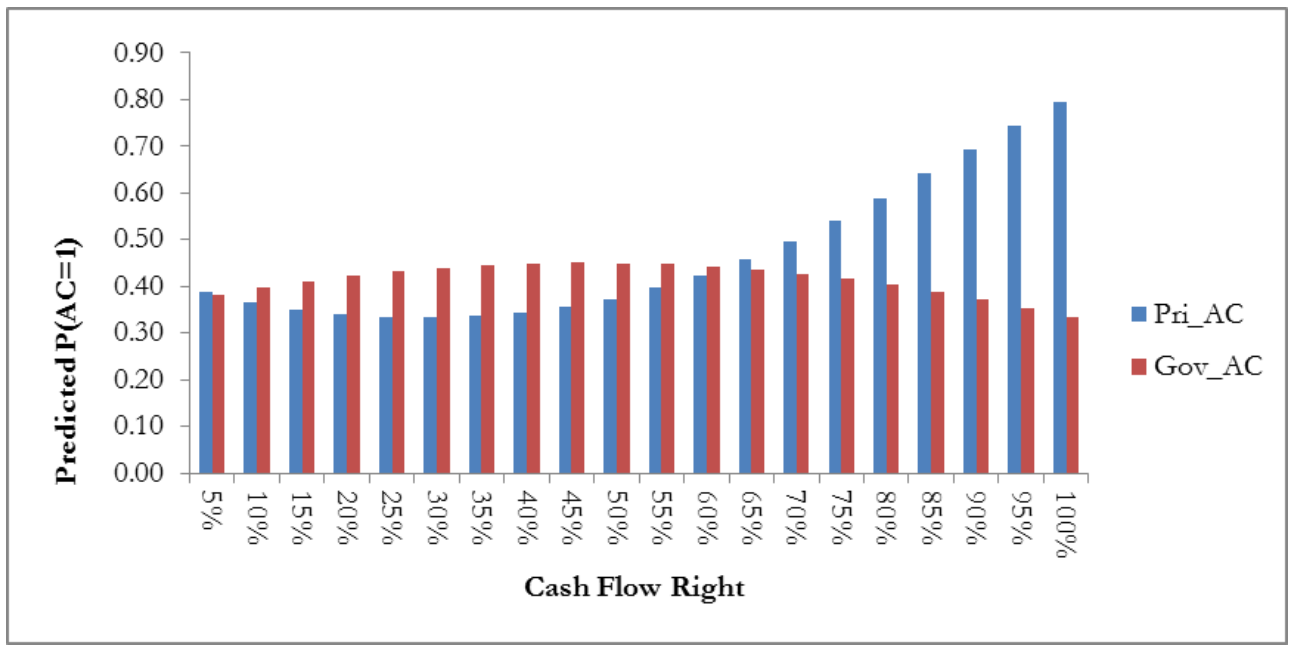

Figure 2b Difference in Predicted Probability that an Audit Committee will exist between State and Privately Controlled Firms

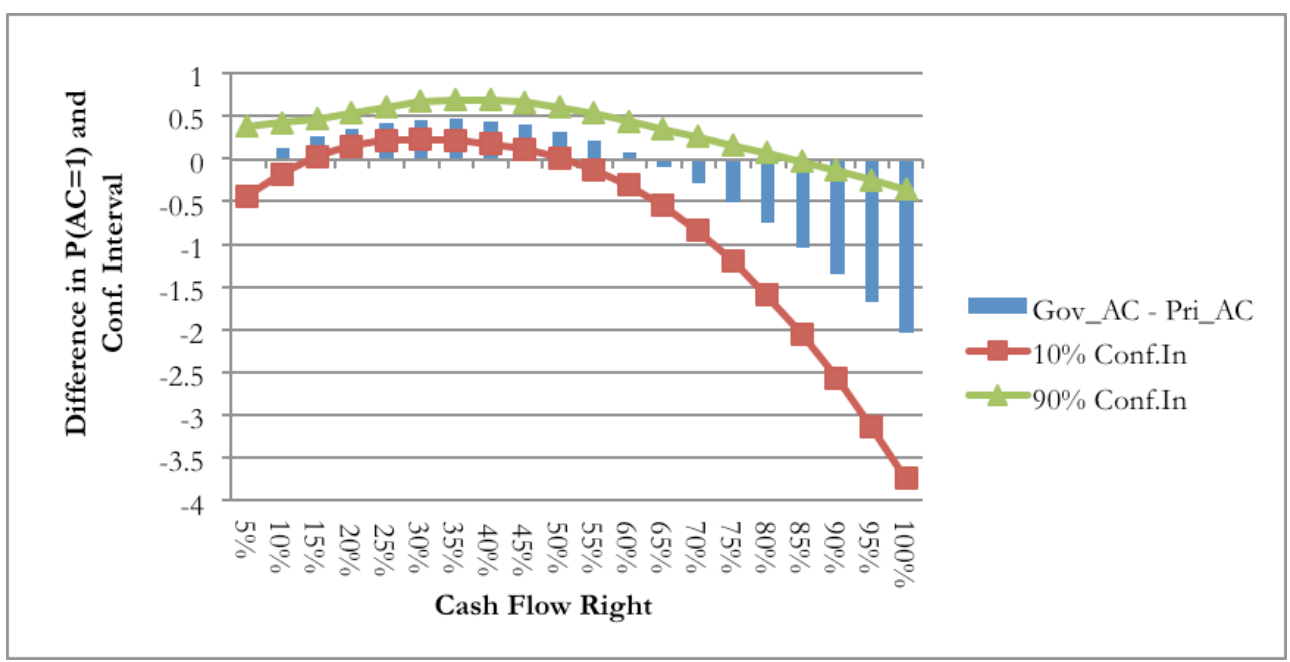

This Figure reports the effects of government control and the level cash flow rights on the predicted probability of an audit committee existing in a company. The predicted probability $\mathrm{P}(\mathrm{AC}=1)$ is calculated using the estimation results reported in Table 5 holding all variables at their mean level except for the level of cash flow rights and setting the indicator variable $g o v=1(g o v=0)$ and other interactive variables (gov_c, gov_csq, gov_vc, gov_pyramid, gov_debt,gov_dirs) accordingly for state (privately) controlled firms. 